Scott's last Polar expedition, is the scene of the following diary entry, dated 9 December 1917.

Shaw came to tea and we had a quiet evening. Shaw told stories of his dreams, and how since he was quite little he has always told himself a story each night before he goes to bed, and some, he said, go on as serials, but others he tells himself over and over again. After dinner we danced and gave Shaw a lesson, both practical and demonstrative.

\title{
Stories and Dreams: II
}

\section{LADY GREGORY}

From Lady Gregory's Journals vol. I, ed. Daniel J. Murphy, Coole Edition xIV (Gerrards Cross: Colin Smythe, 1978) p. 106. Lady Augusta Gregory (18521932), playwright, translator and folklore collector, joined W. B. Yeats in 1898 in successful efforts to found an Irish theatre. Shaw wrote John Bull's Other Island for them in 1904 (the year which saw the opening of the Abbey Theatre in Dublin). In Our Irish Theatre (1914) Lady Gregory mentioned having heard Shaw speak after a public lecture in 1897, but she probably met him through Yeats. By the time she began the Journals in 1916 she was a close friend of the Shaws, and the following recollection, dated 9 November 1919, is taken from an account of one of her numerous visits to Ayot St Lawrence.

Talking of the Dublin statues, he says he had, when a child, a dream one night that he went out and went through the garden, and at the end of it opened a gate and saw the sky all filled with wonderful light, and in the centre was God. And he was in the form of the statue of William III in College Green.

\section{Educational Confessions}

From Bernard Shaw, 'Educational Confessions', The Schoolmistress, 17 November 1927.

What was your favourite subject at school? Has this or some other subject influenced you most in your after-school life? 